\title{
Guaricicana, a new genus of Hyalojassini (Hemiptera: Cicadellidae: Iassinae) from the Brazilian Atlantic Forest
}

\author{
Alexandre C. DOMAHOVSKI ${ }^{1, *} \&$ Rodney R. CAVICHIOLI ${ }^{2}$ \\ ${ }^{1,2}$ Departamento de Zoologia, Universidade Federal do Paraná. \\ Caixa Postal 19020, 81531-980 Curitiba, PR, Brazil. \\ *Corresponding author: domahovskiac@yahoo.com.br \\ 2Email: cavich@ufpr.br \\ ${ }^{1}$ urn:1sid:zoobank.org:author:0B988BD5-599B-42CE-ADCB-50FC813E104E \\ ${ }^{2}$ urn:lsid:zoobank.org:author:58DD5B1D-2A8E-4504-B427-6A6E18E87498
}

\begin{abstract}
A new monotypic genus of Iassinae Walker, 1870 tribe Hyalojassini Evans, 1972 is proposed based on Guaricicana borgesi gen. et sp. nov. from the states of Paraná and Rio de Janeiro, southern and southeastern Brazil, respectively. Detailed descriptions and illustrations of males and females are provided, as well as comparisons with the presumably more closely related genus, Daveyoungana Blocker \& Webb, 1992.
\end{abstract}

Keywords. Daveyoungana, leafhoppers, morphology, Neotropical region, taxonomy.

Domahovski A.C. \& Cavichioli R.R. 2019. Guaricicana, a new genus of Hyalojassini (Hemiptera: Cicadellidae: Iassinae) from the Brazilian Atlantic Forest. European Journal of Taxonomy 547: 1-12.

https://doi.org/10.5852/ejt.2019.547

\section{Introduction}

Cicadellidae Latrielle, 1825 is the largest family of Hemiptera Linnaeus, 1758 and represent one of the most successful radiations of plant-feeding insects that comprising more than 22000 described species, currently classified into 25 subfamilies (Krishnankutty et al. 2016). The subfamily Iassinae Walker, 1870 is distributed worldwide and includes more than 2000 species and 164 genera, currently placed in 12 tribes (Dai et al. 2015; Dai \& Dietrich 2015; Freytag 2015; Krishnankutty et al. 2016; Gonçalves et al. 2017; Domahovski \& Cavichioli 2018, 2019; Domahovski et al. 2019). Iassines are mostly arboreal and many species appear to specialize on particular genera or species of woody plants, although the host associations of most known species remain undocumented (Krishnankutty et al. 2016).

Krishnankutty et al. (2016) estimated the phylogeny of Iassinae based on combined morphological and molecular data from multiple gene regions and provided revised diagnoses and key to the tribes of Iassinae. 
Hyalojassini currently comprises 36 SE Asian and New World genera, this distribution represents an interesting biogeographical disjunction (Dai et al. 2015; Krishnankutty et al. 2016). Most of the 131 described species of Hyalojassini are in the Neotropical region, with 27 genera and 101 species recorded. Only nine genera and 30 species are know from the Oriental region. However, the Neotropical fauna of Hyalojassini remains poorly known, especialy the Brazilian. Only 11 genera and 17 species are recorded from Brazil: Absheta stramineus Baker, 1900; Baldriga rutasaca Blocker, 1979; Comanopa fasciata (Linnavuori, 1956); Daveyoungana blockeri Domahovski \& Cavichioli, 2019; D. collosa Blocker \& Webb, 1992; D. longibrachia Domahovski \& Cavichioli, 2019; D. pentacorni Domahovski \& Cavichioli, 2019; Garlica exila Blocker, 1979; G. punctulata (Linnavuori, 1956); Gehundra pallidus (Osborn, 1924); G. sordida (Baker, 1900); Maranata nigrifrons (Osborn, 1924); Momoria divisa (Stål, 1862); M. menisica Blocker, 1979; Penestragania confusa (Linnavuori, 1956); Stragania ornatula (Stål, 1862) and Webaskola smithii Baker, 1900.

This study aims to describe a new genus based on nine males and three females from the state of Paraná and one female from the state of Rio de Janeiro.

\section{Material and methods}

The descriptive terminology adopted herein mainly follows Young $(1968,1977)$, except for head features (Hamilton 1981; Mejdalani 1998), wings (Dietrich 2005) and leg chaetotaxy (Rakitov 1997). The term "gonoplac" follows Mejdalani (1998). The techniques used for dissection of male and female terminalia follow Oman (1949), with the few modifications described by Cavichioli \& Takiya (2012).

Digital images of habitus, head, wings and male genitalia were obtained with the stereo microscope Leica MZ12.5 connected with the digital camera EC3 and stacked using the CombineZ5 software. Illustrations of male genitalia were drawn with Adobe Illustrator CS6. First and second valvulae and gonoplac were separated and mounted on a temporary slide containing one drop of glycerin and covered with coverslip. Digital images were taken with the optical microscope OlimpusBX50 connected with the USB camera SCMOS 05000KPA. The images were obtained sequentially, from the base to the apex of each structure, with an overlap of about $50 \%$ between images and $100 \times$ magnification. Images were combined with Adobe Photoshop CS6 using the photomerge command. The apex of the first and second valvulae was taken at $100 \times$ magnification and images were stacked using the CombineZ5 software. Photographs and stacked images were modified with Adobe Photoshop CS6.

Label data are specified between quotation marks, with a backslash $(\backslash)$ separating the lines on the labels and a semicolon separating the labels attached to the same specimen. Square brackets ([]) are used to indicate additional abbreviated information by the authors.

The specimens are deposited in the Coleção Entomológica Pe. Jesus Santiago Moure, Universidade Federal do Paraná, Curitiba, Brazil (DZUP) and Illinois Natural History Survey, Prairie Research Institute, University of Illinois at Urbana-Champaign, IL, USA (INHS).

$$
\begin{aligned}
& \text { Abbreviations } \\
& \begin{array}{ll}
\mathrm{AD}=\text { anterodorsal } \\
\mathrm{AV}=\text { anteroventral } \\
\mathrm{PD}=\text { posterodorsal } \\
\mathrm{PV}=\text { posteroventral } \\
\mathrm{IC}=\text { Intercalary }
\end{array}
\end{aligned}
$$




\title{
Results
}

\author{
Family Cicadellidae Latreille, 1825 \\ Subfamily Iassinae Walker, 1870 \\ Tribe Hyalojassini Evans, 1972 \\ Genus Guaricicana gen. nov. \\ urn:Isid:zoobank.org:act:6788EF71-4E7F-4915-ADA3-A2A5AF335714
}

Figs 1-29

\section{Type species}

Guaricicana borgesi gen. et sp. nov.

\section{Diagnosis}

Head (Figs 1-3) wider than pronotum; head surface with transverse parallel striae on crown, anterior margin and frons; crown-face transition rounded. Forewing (Fig. 4) with vein separating appendix and first apical cell complete; appendix and first apical cell having the same texture as rest of forewing. First hind tarsomere (Fig. 9) with inner row formed by cucullate setae. Pygofer (Fig. 12) with basal process on ventral margin. Subgenital plate (Figs 12,15) long, reaching pygofer apical third, but fully covered by sternite VIII. Connective (Fig. 16) present, T-shaped. In dorsal view, style (Fig. 17) elongated, without lateral lobes. Aedeagus (Figs 19-20) shaft very long. Female first valvula (Figs 23-24) with dorsal sculpturing imbricate; ventral margin near apex and apex with sculpturing areolate. Second valvula (Figs 25-26) lacking prominent widely spaced teeth; apical fifth with irregular rounded teeth on dorsal margin and some small teeth on ventral margin near apex.

\section{Etymology}

The generic name Guaricicana (feminine noum), refers to the Reserva Particular do Patrimônio Natural da Guaricica, of the Sociedade em Pesquisa da Vida Selvagem e Educação Ambiental (SPVS), municipality of Antonina, state of Paraná, where the majority of the type-material was collected. The suffix -ana is common for other generic names of Iassinae.

\section{Description}

MEASuREMEnTs. Body length: male 5.8-6.1 mm; female 6.4-6.6 mm.

BoDy. Small to medium-sized leafhoppers, slightly depressed dorsoventraly and moderately elongated.

HEAD (Figs 1-3). Dorsal view: wider than pronotum; not produced anteriorly, median length of crown onetenth interocular width; anterior and posterior margins parallel, broadly rounded; surface with transverse parallel striae; ocelli not visible dorsally; ventral view: face ca twice as wide as high; ocelli small, on anterior margin, mesad antennal pits; antennal ledge closer to anterodorsal than to anteroventral corner of eye, carinate and slightly oblique, not concealing antennal base; frons strongly broader dorsally, with transverse striae, distance between lateral margin of frons and eye internal margin subequal to maximum clypeus width; frontogenal suture not surpassing antennal ledges; gena broader than high, ventral margin excavate below eye internal margin and not completely concealing proepisternum; epistomal suture distinct and complete; clypeus as long as wide, lateral margins approximately straight and convergent apically, apical margin rounded; lateral view: crown slightly concave; crown-face transition rounded, with transverse striae; frons slightly convex; clypeus slightly inflated.

Pronotum (Fig. 1). Surface transversely striated except near anterior margin, anterior margin broadly rounded and produced anterad of eyes medially, lateral margins carinate and shorter than eye length, 

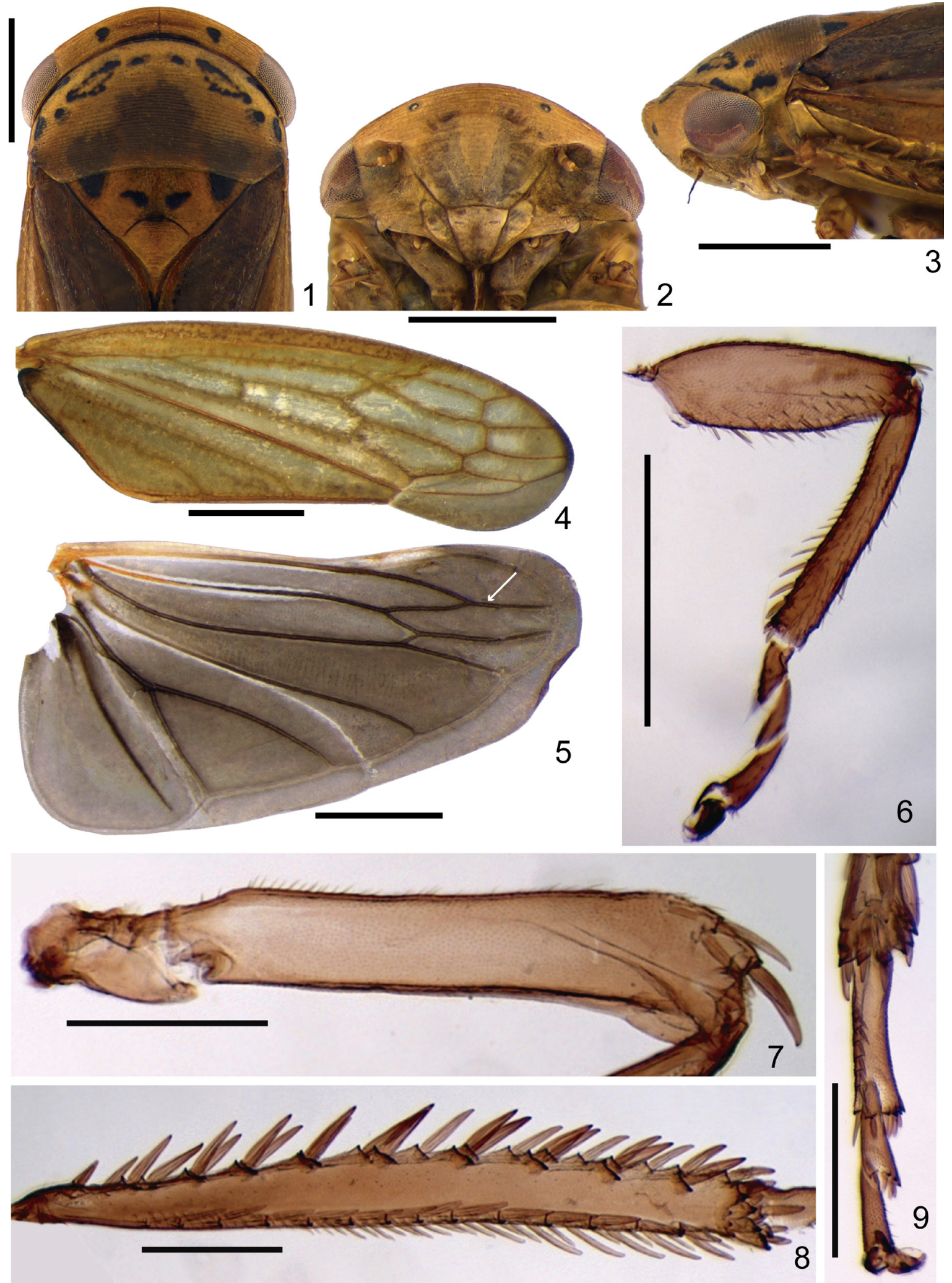

Figs 1-9. Guaricicana borgesi gen. et sp. nov., holotype, đ̊ (DZUP 215374). External morphology. 1. Head and thorax, dorsal view. 2. Head and thorax, ventral view. 3. Head and thorax, lateral view. 4. Fore wing. 5. Hind wing. 6. Fore leg, anterior view. 7. Hind femur, anterior view. 8. Hind tibia, anterior view. 9. Hind tarsus, ventral view. Scale bars: $1-7=1.0 \mathrm{~mm} ; 8-9=0.5 \mathrm{~mm}$. 


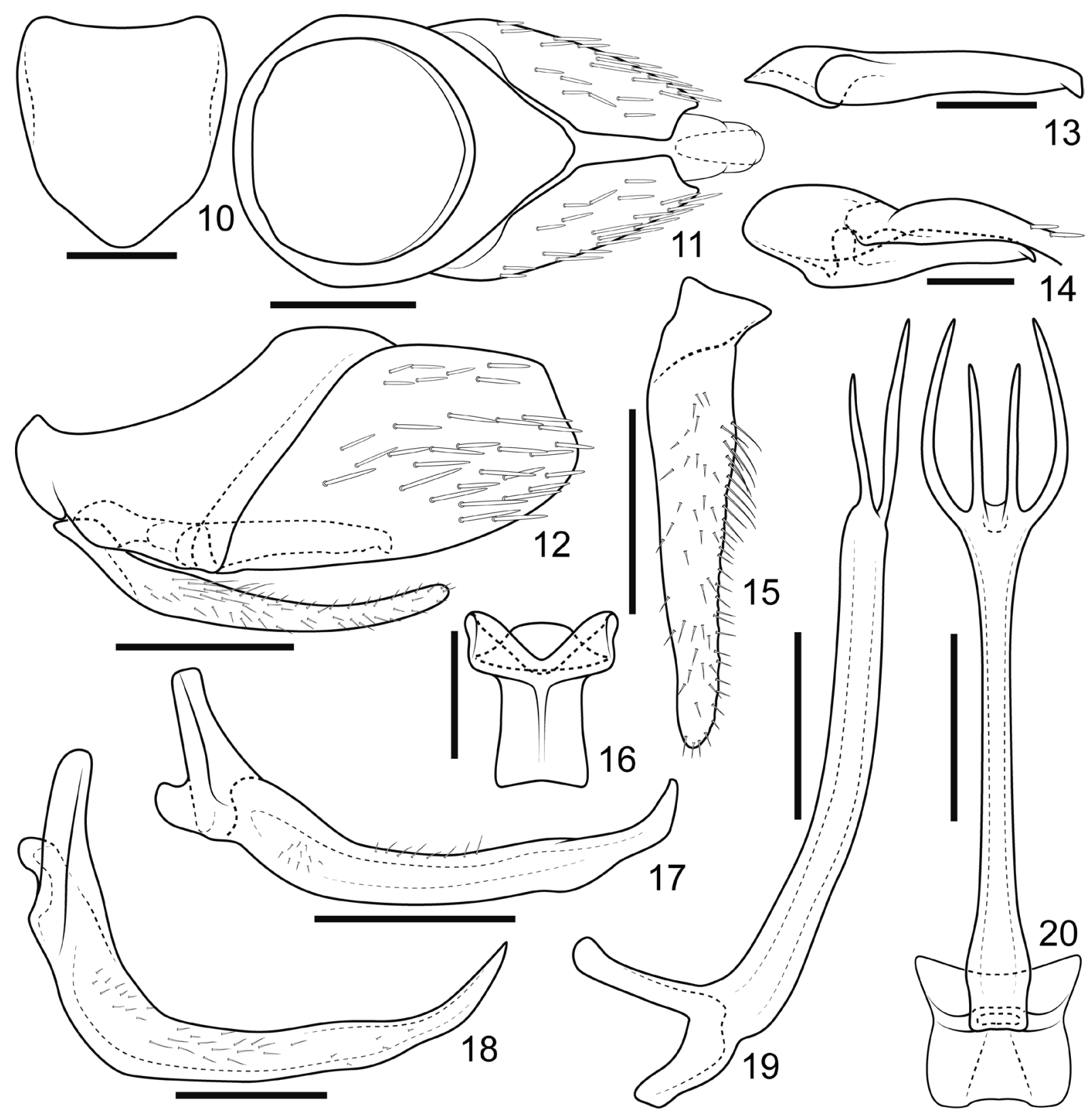

Figs 10-20. Guaricicana borgesi gen. et sp. nov., holotype, $\widehat{\partial}$ (DZUP 215374), terminalia. 10. Sternite VIII, ventral view. 11. Pygofer, dorsal view. 12. Pygofer and subgenital plate, lateral view. 13. Ventral process of pygofer, lateral view. 14. Ventral process of pygofer, ventral view. 15. Subgenital plate, ventral view. 16. Connective, dorsal view. 17. Style, dorsal view. 18. Style, lateral view. 19. Aedeagus, lateral view. 20. Aedeagus, ventral view. Scale bars: $10-12,15,17-18=0.5 \mathrm{~mm} ; 13-14,16,19-20=$ $0.25 \mathrm{~mm}$. 


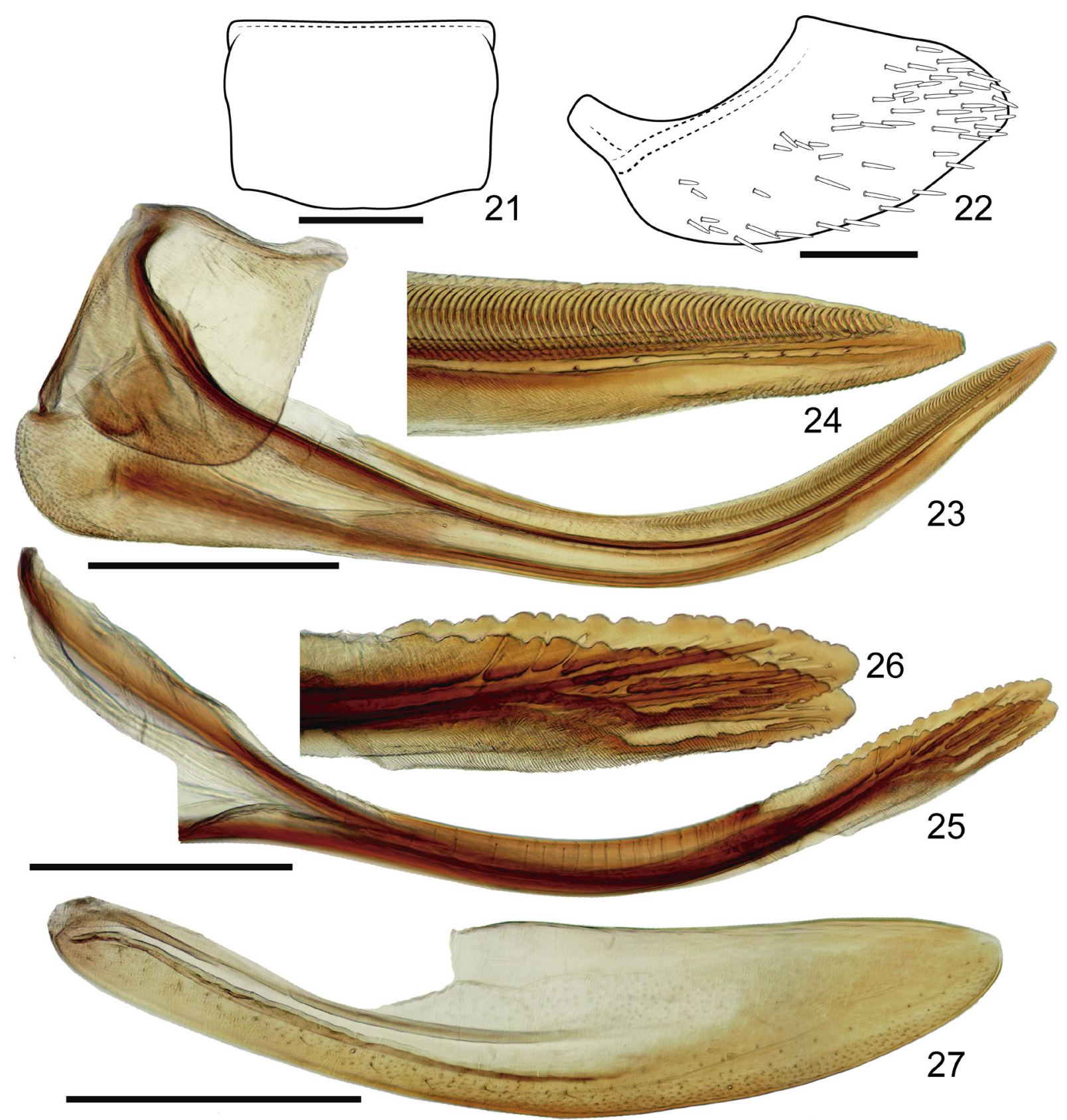

Figs 21-27. Guaricicana borgesi gen. et sp. nov., paratype, $q$ (DZUP 215378), terminalia. 21. Sternite VII, ventral view. 22. Pygofer, lateral view. 23. First valvifer and first valvula, lateral view. 24. Apex of first valvula, lateral view. 25. Second valvula, lateral view. 26. Apex of second valvula, lateral view. 27. Gonoplac, lateral view. Scale bars $=0.5 \mathrm{~mm} ; 24,26=$ not to scale. 
almost parallel; posterior margin slightly excavated; laterally (Fig. 3) slightly declivous; head and pronotum in continuous slope.

Mesonotum (Fig. 1). Slightly wider than long; mesonotum rugulose; scutellum with inconspicuous transverse striae.

ForEWING (Fig. 4). Venation distinct; small setae present laterally to the veins; three closed anteapical and five apical cells present; vein separating appendix and first apical cell complete; appendix and first apical cell having the same texture as rest of forewing; appendix developed, bordering first and second apical cells. Hind wing (Fig. 5) with R4+5 and M1+2 veins fused apically.

LeGs. Profemur (Fig. 6) three times longer than high; AD, AM and PD rows reduced with exception of apical setae AD1, AM1 and PD1, respectively; intercalary group formed by short and irregular double row of setae continuous with AV row; AV row formed by six thicker and longer setae; PV row composed by thin, long setae; protibia (Fig. 6) circular-shaped in cross section; AV row formed by very short setae in basal half, apical half with five longer and thicker setae toward apex; AD row undifferentiated; PD row formed by three longer and thicker setae and short, thin intercalary setae; PV row formed by approximately ten short setae; metafemur (Fig. 7) with setal formula 2:2:1; metatibia (Fig. 8) rows PD, $\mathrm{AD}$, and $\mathrm{AV}$ with 15-16, 10-11, and 12-13 macrosetae, respectively; PV row beginning on median

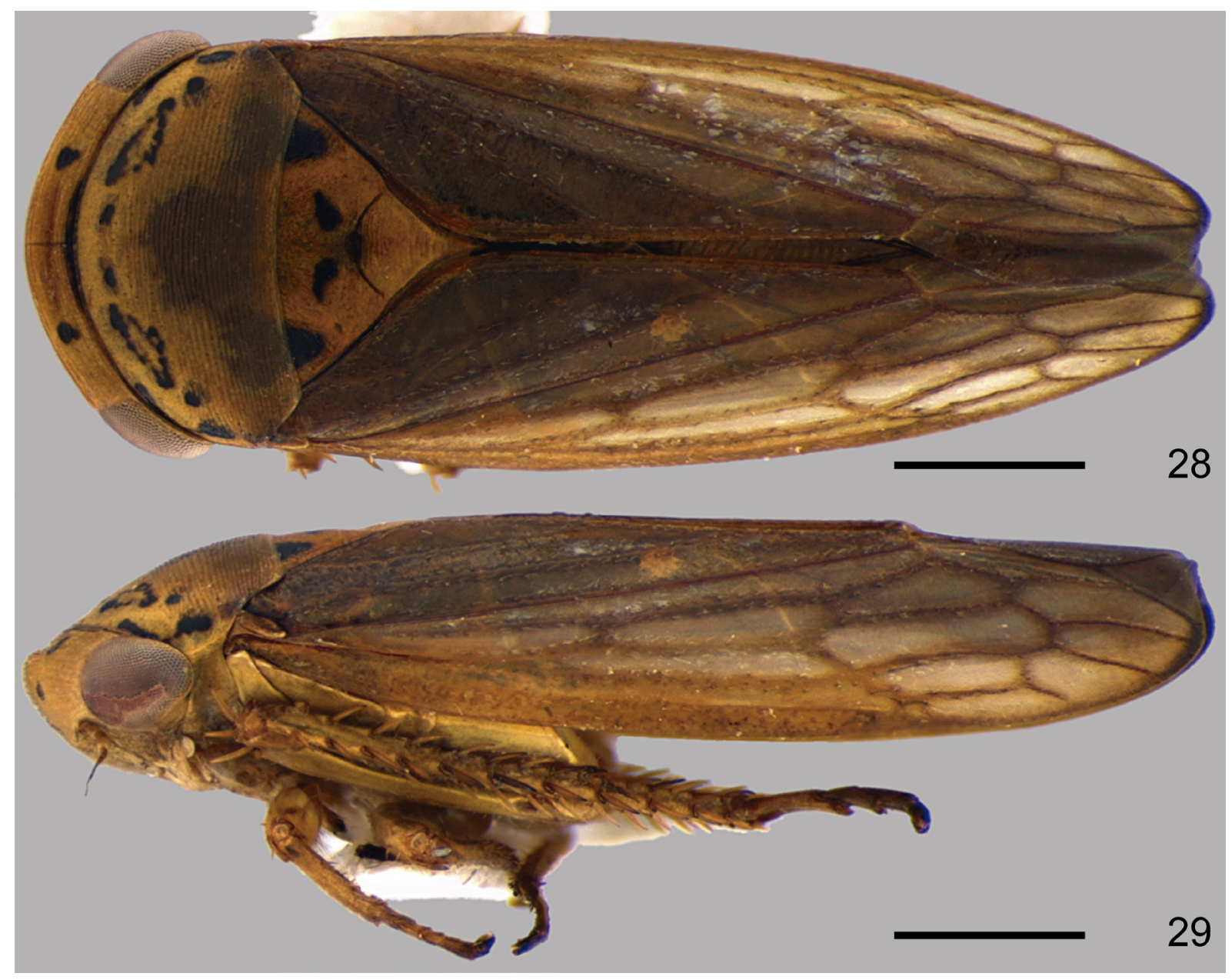

Figs 28-29. Guaricicana borgesi gen. et sp. nov., holotype, $ð$ (DZUP 215374). 28. Dorsal habitus. 29. Lateral habitus. Scale bars $=1 \mathrm{~mm}$. 
third, setae of median third homogeneous in length, setae of apical third alternating short and long setae and ending in two short setae; first tarsomere (Fig. 9) with inner row formed by five-six thick cucullate setae, pecten with four platellae flanked by tapered lateral setae; second tarsomere (Fig. 9) shorter than half of first tarsomere length, pecten with two apical platellae, flanked by tapered lateral setae.

Male terminalia. Sternite VIII (Fig. 10) triangular, strongly produced posterad and fully hiding subgenital plates. Pygofer (Fig. 12) with basal process on ventral margin. Subgenital plate (Figs 12, 15) long, reaching pygofer apical third. Connective (Fig. 16) present, T-shaped. In dorsal view, style (Fig. 17) elongated, without lateral lobes. Aedeagus (Figs 19-20) shaft long.

Female terminalia. Pygofer (Fig. 22) with numerous macrosetae except on anterodorsal portion. Valvulae (Figs 23, 25) slender, not surpassing pygofer apex, curved dorsally. First valvula (Figs 23-24) with dorsal sculpturing imbricate, starting at midlength to near apex; apical portion (Fig. 24) with ventral margin near apex and apex with sculpturing areolate, apex gradually tapered. Second valvula (Figs 25-26) apical fifth with irregular rounded teeth on dorsal margin and some small teeth on ventral margin near apex. Gonoplac (Fig. 27) higher at midlength; dorsal margin straight; ventral margin slightly rounded with few and sparse setae except on apical portion; apex rounded.

\section{Distribution}

Brazil (Paraná and Rio de Janeiro).

\section{Remarks}

The new genus is placed within Hyalojassini in having the head with the transition crown to face rounded in profile; the ocelli on anterior margin not visible in dorsal view; the hind wing with $\mathrm{R} 4+5$ and $\mathrm{M} 1+2$ veins fused apically; and the sternite VIII of male fully hiding the subgenital plates. Guaricicana gen. nov. is very similar to Daveyoungana Blocker \& Webb, 1992 in the body shape, slightly depressed dorsoventrally and moderately elongated; the position of the black spots of the head and the pronotum; the head wider than pronotum; the fore wing with a vein separating the appendix and the first apical cell complete, and the appendix and the first apical cell with the same texture as the remainder of the fore wing; the chaetotaxy of the legs, except for the first hind tarsomere; the pygofer with a well sclerotized basal portion, forming a ring dorsally, the presence of a basal process on the ventral margin and the lateral lobes with many macrosetae, articulated with the base by flexible membranous clefts; the large T-shaped connective; the style with an elongated apophysis; the aedeagus shaft elongated; and the female first valvula with an imbricate dorsal sculpturing and a ventral margin and apex with sculpturing areolate.

However, Daveyoungana can easily be separated from Guaricicana gen nov. by the coloration of the forewing with a yellow costal margin; the first hind tarsomere with a row of simple (non-cucullate) setae on the ventral surface; a short subgenital plate, approximately as long as wide; the connective with a longer stalk; the style with lateral lobes; and the female second valvula with three prominent widely spaced teeth in the distal half.

Guaricicana borgesi gen. nov. et sp. nov. urn:lsid:zoobank.org:act:40A16D4E-0170-4D26-8AAD-6F86552DCDD8

Figs 1-29

\section{Diagnosis}

As for the genus. 


\section{Etymology}

The new species is named in honor to Dr Clóvis Borges, executive director of SPVS (Sociedade de Pesquisa em Vida Selvagem e Educação Ambiental) that includes the Reserva Natural Guaricica, previously named Reserva Natural Rio Cachoeira.

\section{Material examined}

Holotype

BRAZIL • đ̃; "Brasil, PR [Paraná], Antonina $\backslash$ Res. [Reserva] Rio Cachoeira $\backslash 25.316^{\circ} \mathrm{S} 48.696^{\circ} \mathrm{W} \backslash 50 \mathrm{~m}$, 05-10.XI.2015\ Luminosa suspensa Entomologia UFPR”; DZUP 215374.

\section{Paratypes}

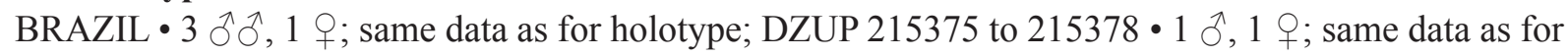
holotype; INHS • 1 o, 1 \&; same data as for holotype except 20-25 Nov. 2014; DZUP 215379 to 215380 - 1 ठ̊’; "Brasil, Paraná, Antonina, $\backslash$ Res. [Reserva] Nat. [Natural] Guaricica, 50m, $\backslash 25.316^{\circ} \mathrm{S} 48.696^{\circ}$ W, 05-09.XI.2018 L.[Luminosa] suspen- $\backslash$ sa Entomologia UFPR”; DZUP 215381 • 1 ○े; "Brasil, PR, Antonina $\backslash$ Res. Rio Cachoeira 50m $\backslash 25.316^{\circ} \mathrm{S} 48.696^{\circ} \mathrm{W} \backslash 23-27 . I .2017 \backslash$ L. [Luminosa] suspensa Entomologia UFPR"; DZUP 215382 • 1 సె; "Brasil, PR, Antonina, Res. [Reserva] Nat. [Natural] Guaricica (Rio Cachoeira) $\backslash 25.316^{\circ} \mathrm{S} 48.696^{\circ} \mathrm{W}$ 50m $\backslash 16-20 . V .2018$ Luminosa Susp. [Suspensa] $\backslash$ R.R. Cavichioli \& A.P. Pinto"; DZUP 215383 • 1 क; "RJ [Rio de Janeiro], Brasil, P.N. [Parque Nacional] Itatiaia \Casa do Pesquisador, $\backslash$ light 27-30.X.2011 800m $\backslash 22.454^{\circ} \mathrm{S} 44.608^{\circ} \mathrm{W} \backslash$ R.R. Cavichioli”; DZUP 215384.

\section{Description}

MoRPHOLOGy. External morphological characters as in generic description.

Coloration (male and female). Head and thorax (Figs 1-3) yellowish brown. Crown with pair of rounded black spots equidistant between eye margin and median line. Face (Fig. 2) without maculae. Pronotum (Figs 1,3) with black markings near anterior margin; disk and posterior third dark-brown. Mesonotum (Fig. 1) with two pairs of black spots, one pair near lateral angles and one medially near scutellum; scutoscutelar suture black. Forewing (Figs 4, 28-29) yellowish brown; membrane translucent; appendix smoky. Hind wing (Fig. 5) grey with darker veins. Legs (Fig. 29) yellowish brown.

MALE TERMinalia. Sternite VIII (Fig. 10) longer than wide; lateral margins slightly rounded; apex tapered and rounded. In dorsal view, pygofer (Fig. 11) with basal portion well sclerotized forming unbroken ring dorsally; lateral lobe articulated with base by flexible membranous cleft and approximately as long as basal portion; macrosetae dispersed on lateral lobe except on anteroventral portion; apex obliquely truncated. Ventral process of pygofer (Figs 12-14) slender, almost straight, slightly shorter than subgenital plate; laterally with small rounded lobe near base, apex acute and bent ventrally. Subgenital plate (Fig. 15) slender and slightly tapered to apex, 5.5 times longer than wide; setae on ventral surface and external margin; apex rounded. Connective (Fig. 16) slightly longer than basal width; stalk very wide, straight, with keel dorsally. In dorsal view, style (Fig. 17) with apodeme moderately short, produced laterally; apophysis elongate, slender, apex slightly directed laterally; microsetae present, forming small group near base of apophysis and dispersed laterally on mid-portion; in lateral view (Fig. 18), apodeme directed dorsally; apophysis curved near base, tapered towards apex; apex acute, slightly curved dorsally. Aedeagus (Figs 19-20) with preatrium and dorsal apodeme developed, flattened, twice as wide as shaft; shaft very long, almost straight, weekly compressed laterally, except for apex and base; shaft apex with two pairs of processes directed dorsally, lateral pair slightly arched and longer than median pair, which is shorter and straight. 
Female terminalia. Sternite VII (Fig. 21) 1.5 times wider than long, approximately rectangular; posterior margin broadly rounded, slightly produced posteriorly on median potion medially. Pygofer (Fig. 22) about two times as long as maximum height; ventral margin broadly rounded; apex tapered and rounded. First valvifer (Fig. 23) as high as long, margins straight, posteroventral corner rounded.

\section{Remarks}

The clypeus and lorum of the male specimens are morphologically similar to those of the females. It differs from species of Daveyoungana that have the clypeus and lorum sexually dimorphic, as described by Dai \& Dietrich (2015). The specimens from the state of Paraná were collected with a suspense light trap placed at approximately $20 \mathrm{~m}$ above the soil.

\section{Discussion}

The new genus does not key out correctly in the key to the tribes of Iassinae proposed by Krishnankutty et al. (2016) because the subgenital plates are elongated, in which it differs from the other members of Hyalojassini, which have the subgenital plates shorter or absent. The hind wing of the new genus is typical of the Hyalojassini with the R4+5 and M1+2 veins fuse distally, in which they differ from the other Neotropical tribes (Bythoniini Linnavouri, 1959; Gyponini Stål, 1870; Hoplojassini Krishnankutty et al., 2016; Lipokrisnini Krishnankutty et al., 2016; and Selenomorphini Evans, 1974) that have the hind wing with veins R4+5 and M1+2 separated distally. Besides that, Guaricicana gen. nov.is more similar to members of Hyalojassini, especially to Daveyoungana, in several morphological characters, as discussed in the remarks of the new genus. The female first valvula of Guaricicana gen. nov. is very similar to the first valvula of Daveyoungana in the overall shape and imbricate dorsal sculpturing. This character differs from the other hyalojassines that usually have the dorsal sculpturing areolate (Krishnankutty et al. 2016). The second valvula of the new genus lacks the two or three prominent widely spaced teeth, which are present in Daveyoungana and in other hyalojassines.

Based on those morphological differences and in the fact that Daveyoungana was not included in any phylogenetic hypotheses including the one provided by Krishnankutty et al. (2016), a future phylogenetic study is needed to ascertain whether Guaricicana gen. nov. and Daveyoungana are sister groups or not, as well as their position in the tree of iassines.

\section{Acknowledgements}

We thank the Conselho Nacional de Desenvolvimento Científico e Tecnológico (CNPq) for fellowships provided to A.C. Domahovski (process 140815/2017-1) and R.R. Cavichioli (process 305484/2014-1). Many thanks to the anonymous reviewers who kindly made improvements to a preliminary version of this manuscript and the editorial team of the EJT. Thanks to Reginaldo Antunes Ferreira, Manager of the RPPN da Guaricica. We also thank Taxonline (Rede Paranaense de Coleções Biológicas, UFPR) for the images of the female genitalia. Thanks to C. Dietrich for the contribution about the identification of this new genus. This paper is the contribution number 1966 of the Departamento de Zoologia, Universidade Federal do Paraná.

\section{References}

Cavichioli R.R. \& Takiya D.M. 2012. Description of a new species of Wolfniana and new records of Rotigonalia (Hemiptera: Cicadellidae: Cicadellinae) from the state of Amazonas, Brazil. Zoologia 29 (1): 85-88. https://doi.org/10.1590/S1984-46702012000100011

Dai W. \& Dietrich C.H. 2015. A new genus of Iassinae (Hemiptera: Cicadellidae) from Peru and a new species of Daveyoungana Blocker \& Webb. Zootaxa 3946 (2): 285-295. https://doi.org/10.11646/zootaxa.3946.2.10 
Dai W., Dietrich C.H. \& Zhang Y. 2015. A review of the leafhopper tribe Hyalojassini (Hemiptera: Cicadellidae: Iassinae) with description of new taxa. Zootaxa 3911 (1): 1-42. https://doi.org/10.11646/zootaxa.3911.1.1

Dietrich C.H. 2005. Keys to the families of Cicadomorpha and subfamilies and tribes of Cicadellidae (Hemiptera: Auchenorrhyncha). Florida Entomologist 88: 502-517.

Domahovski A.C. \& Cavichioli R.R. 2018. Two new remarkable genera and two new species of Gyponini (Hemiptera: Cicadellidae: Iassinae) from Brazil. European Journal of Taxonomy 476: 1-17. https://doi.org/10.5852/ejt.2018.476

Domahovski A.C. \& Cavichioli R.R. 2019. Three new species of Daveyoungana Blocker \& Webb (Hemiptera: Cicadellidae: Iassinae: Hyalojassini) from Brazil. Zootaxa 4571(4): 477-488. https://doi.org/10.11646/zootaxa.4571.4.2

Domahovski A.C., Gonçalves C.C., Takiya D.M. \& Cavichioli R.R. 2019. Two new genera and species of Gyponini (Hemiptera: Cicadellidae) from South America. Zootaxa 4568(3): 561-570. https://doi.org/10.11646/zootaxa.4568.3.9

Freytag P.H. 2015. Four new genera and nine new species related to the genus Hecalapona (Hemiptera: Cicadellidae: Gyponinae). Entomological News 124 (4): 245-264. https://doi.org/10.3157/021.124.0402

Gonçalves C.C., Takiya D.M. \& Mejdalani G. 2017. Sakakibarana, a new genus of Gyponini (Hemiptera: Cicadellidae: Iassinae) from the Amazon Rainforest. Zootaxa 4281 (1): 219-224. https://doi.org/10.11646/zootaxa.4281.1.20

Hamilton K.G.A. 1981. Morphology and evolution of the Rhynchotan head (Insecta: Hemiptera, Homoptera). Canadian Entomologist 113: 953-974. https://doi.org/10.4039/Ent113953-11

Krishnankutty S.M., Dietrich C.H., Dai W. \& Siddappaji M.H. 2016. Phylogeny and historical biogeography of leafhopper subfamily Iassinae (Hemiptera: Cicadellidae) with a revised tribal classification based on morphological and molecular data. Systematic Entomology 41 (3): 580-595. https://doi.org/10.1111/syen.12175

Mejdalani G. 1998. Morfologia externa dos Cicadellinae (Homoptera, Cicadellidae): comparação entre Versigonalia ruficauda (Walker) (Cicadellini) e Tretogonia cribrata Melichar (Proconiini), com notas sobre outras espécies e análise da terminologia. Revista Brasileira de Zoologia 15: 451-544. https://doi.org/10.1590/S0101-81751998000200015

Oman P.W. 1949. The Nearctic leafhoppers (Homoptera: Cicadellidae). A generic classification and check list. Memoirs of the Entomological Society of Washington 3. The Entomological Society of Washington, Washington D.C.

Rakitov R.A. 1997. On differentiation of cicadellid leg chaetotaxy (Homoptera: Auchenorrhyncha: Membracoidea). Russian Entomological Journal 6: 7-27.

Young D.A. 1968. Taxonomic study of the Cicadellinae (Homoptera: Cicadellidae), Part 1, Proconiini. Bulletin of the United States National Museum 261: 1-287. https://doi.org/10.5962/bhl.part.20869

Young D.A. 1977. Taxonomic study of the Cicadellinae (Homoptera: Cicadellidae). Part 2. New World Cicadellini and the genus Cicadella. Bulletin of North Carolina Agricultural Experiment Station 239: $1-1135$. 
Manuscript received: 23 November 2018

Manuscript accepted: 27 May 2019

Published on: 3 September 2019

Topic editor: Gavin Broad

Section editor: Anna Namyatova

Desk editor: Jeroen Venderickx

Printed versions of all papers are also deposited in the libraries of the institutes that are members of the EJT consortium: Muséum national d'Histoire naturelle, Paris, France; Meise Botanic Garden, Belgium; Royal Museum for Central Africa, Tervuren, Belgium; Royal Belgian Institute of Natural Sciences, Brussels, Belgium; Natural History Museum of Denmark, Copenhagen, Denmark; Naturalis Biodiversity Center, Leiden, the Netherlands; Museo Nacional de Ciencias Naturales-CSIC, Madrid, Spain; Real Jardín Botánico de Madrid CSIC, Spain; Zoological Research Museum Alexander Koenig, Bonn, Germany; National Museum, Prague, Czech Republic. 